\title{
QUARTERLY RESEARCH REPORT
}

(Reporting Period: 10/01/96 - 12/31/96)

ON

$$
\text { DOE/MC/31426--9 }
$$

Characterization and Optimization of Sorbents Utilized

For

Emission Control During Coal Gasification

Program Identification Number : DE-FG21-94MC31426 - - 9

\author{
Submitted To : Ms. Carla J. Winaught \\ United States Department Of Energy \\ Morgantown Energy Technology Center
}

\section{BY}

Dr. Zaiul Huque, Dr. Daniel Mei and Dr. Jianren Zhou

Mechanical Engineering / Prairie View A\&M University

College Of Engineering And Architecture

P.O. Box 397

Prairie View, Texas 77446-0397

TEL: (409) 857 - 4023

FAX: (409) 857-4395

Date: January 23, 1997

DISTRISUTION OF THIS DOCUMENT IS UNLIMITED
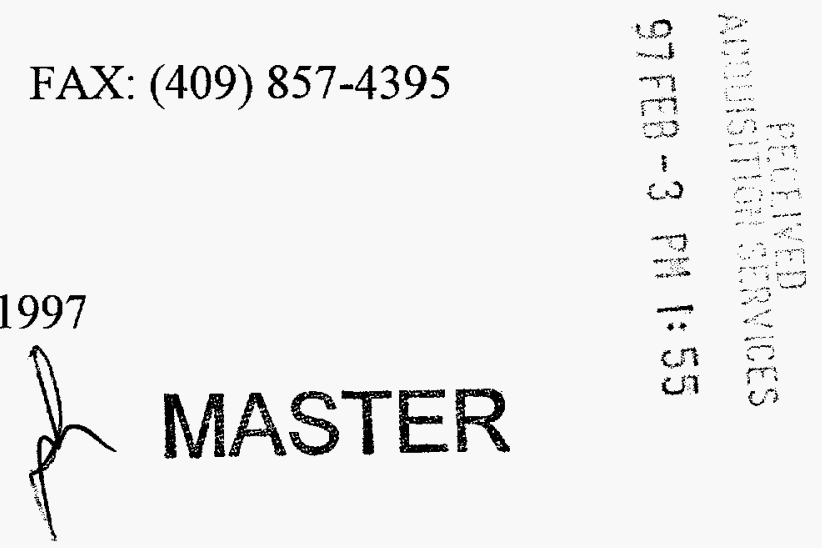


\section{DISCLAIMER}

This report was prepared as an account of work sponsored by an agency of the United States Government. Neither the United States Government nor any agency thereof, nor any of their employees, makes any warranty, express or implied, of assumes any legal liability or responsibility for the accuracy, completeness, or usefulness of any information, apparatus, product, or process disclosed, or represents that its use would not infringe privately owned rights. Reference herein to any specific commercial product, process, or service by trade name, trademark, manufacturer, or otherwise does not necessarily constitute or imply its endorsement, recommendation, or favoring by the United States Government or any agency thereof. The views and opinions of authors expressed herein do not necessarily state or reflect those of the United States Government or any agency thereof. 


\section{DISCLAIMER}

Portions of this document may be illegible electronic image products. Images are produced from the best available original document. 
The major sorbent research activities in the reporting period 10/01/96 to12/31/96 at PVA\&MU are summarized as follows:

- A no-cost extension request was submitted to extend the complete schedule to the middle of 1997

- The techniques to interface PC with programmable instrumentation for automatic data acquisition were established. These techniques include interfacing instrumentation with the use of IEEE-488, and RS-485. The accomplishment provided a good foundation of building a more sophisticated PC controlled data acquisition system for a more complicated desulfurization test system using more instruments and performing more testing control.

- The main efforts were spent on interfacing the test instruments with the personal computer with the use of a virtual instrumentation program developed by National Instruments Company. A lot of work were performed by understanding the software, programming interfacing and adjusting the timing coordination between the PC and the instruments.

- A gas mixture pressure vessel has been assembled, photographs are attached. Perform preliminary study of using a gas chromatograph to analyze the gas to be tested in the sorbent test system. The photograph of the gas chromatograph is also attached.

- The photographs show details of the Sorbent test setup 


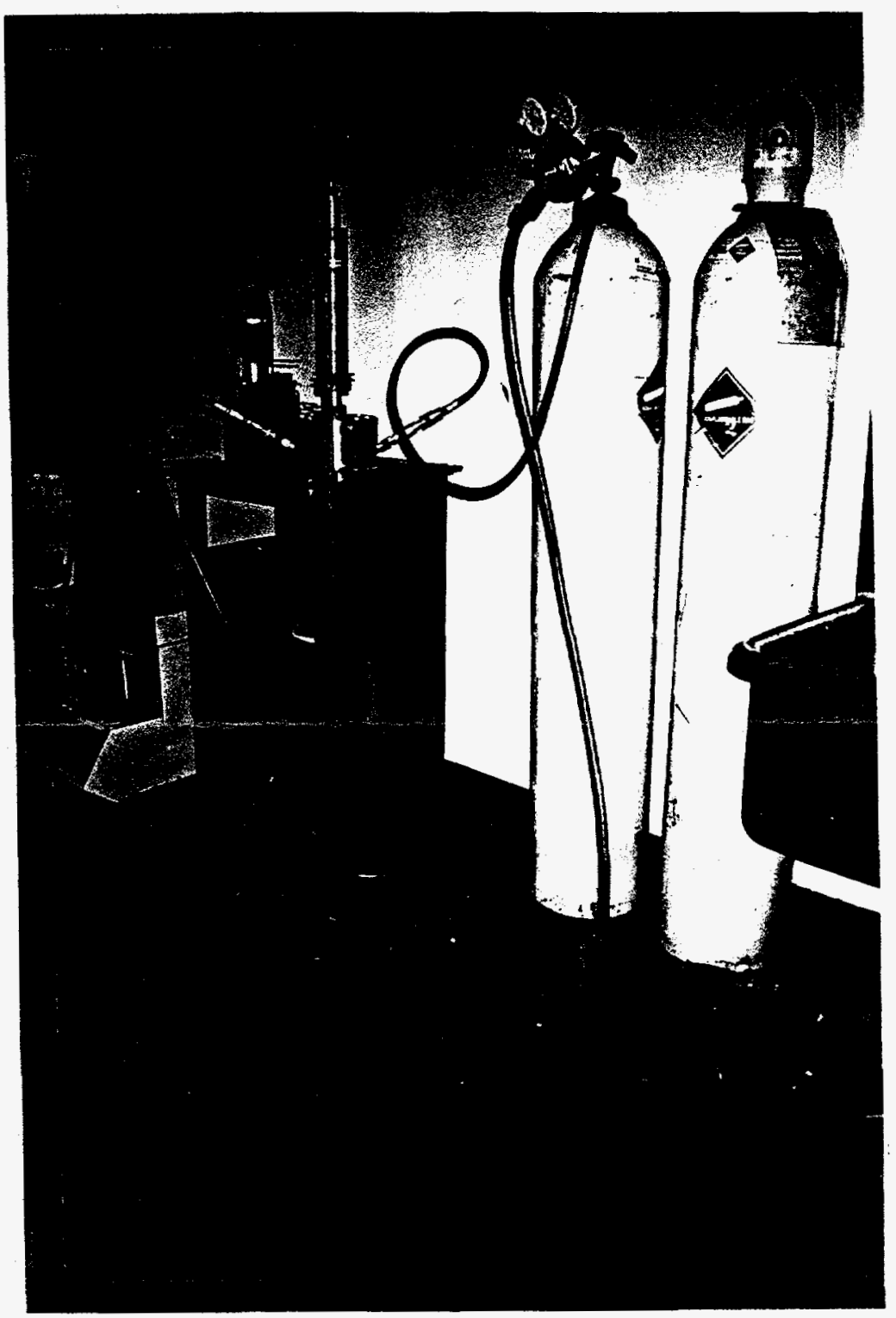

SORBENT TEST SETUP ASSEMBLY 


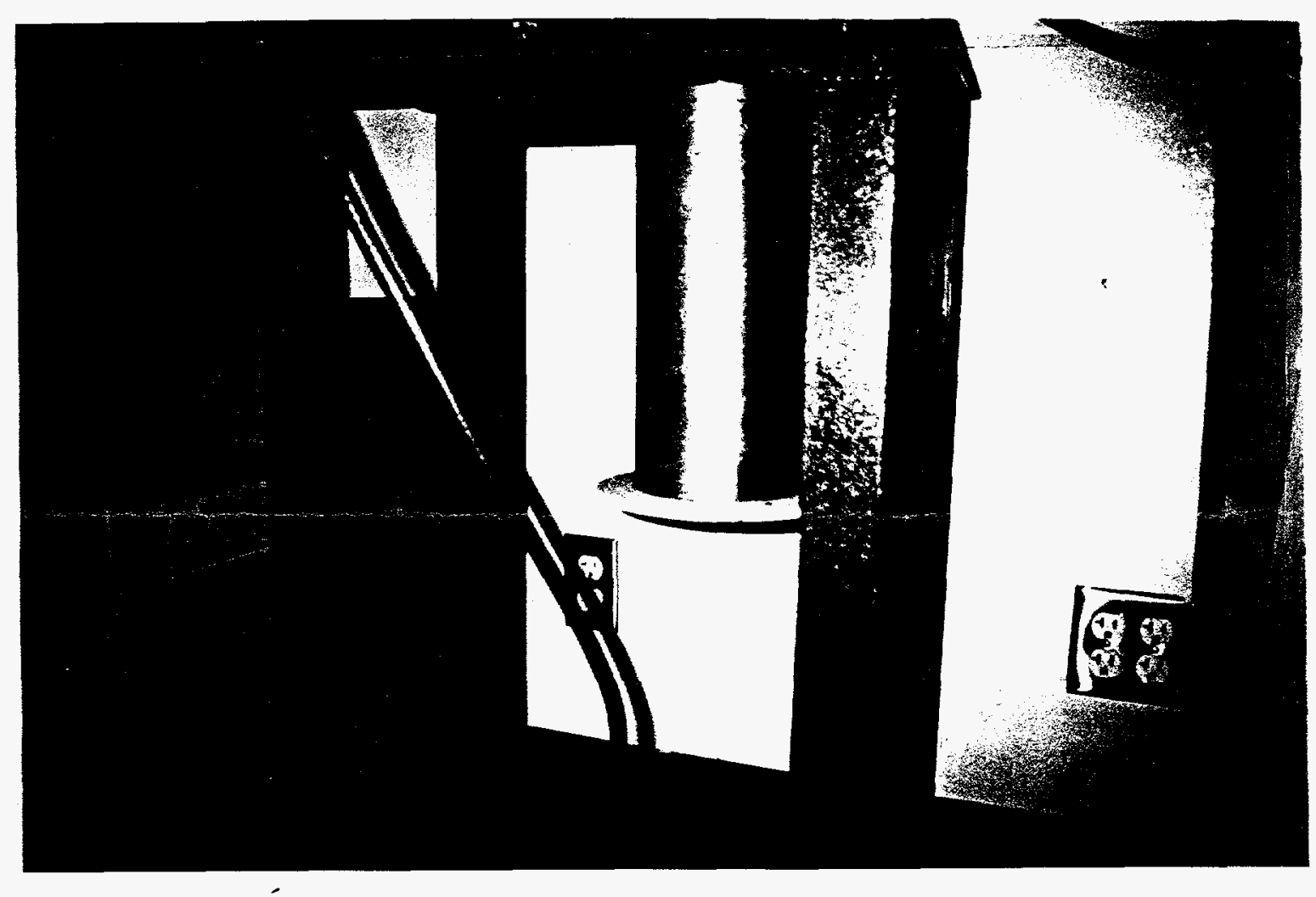

SORBENT TEST VESSEL 


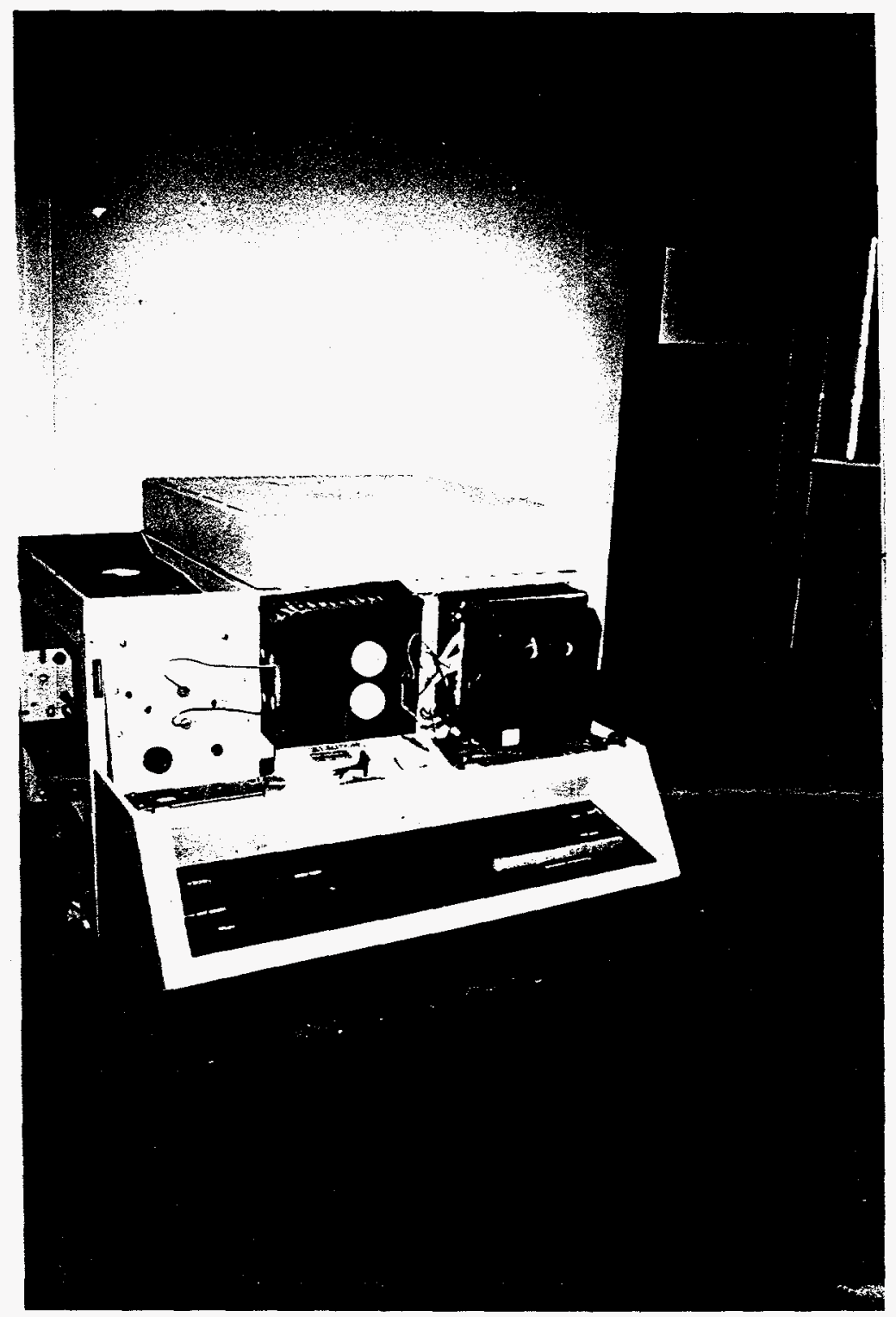

GAS CHROMATOGRAPH 


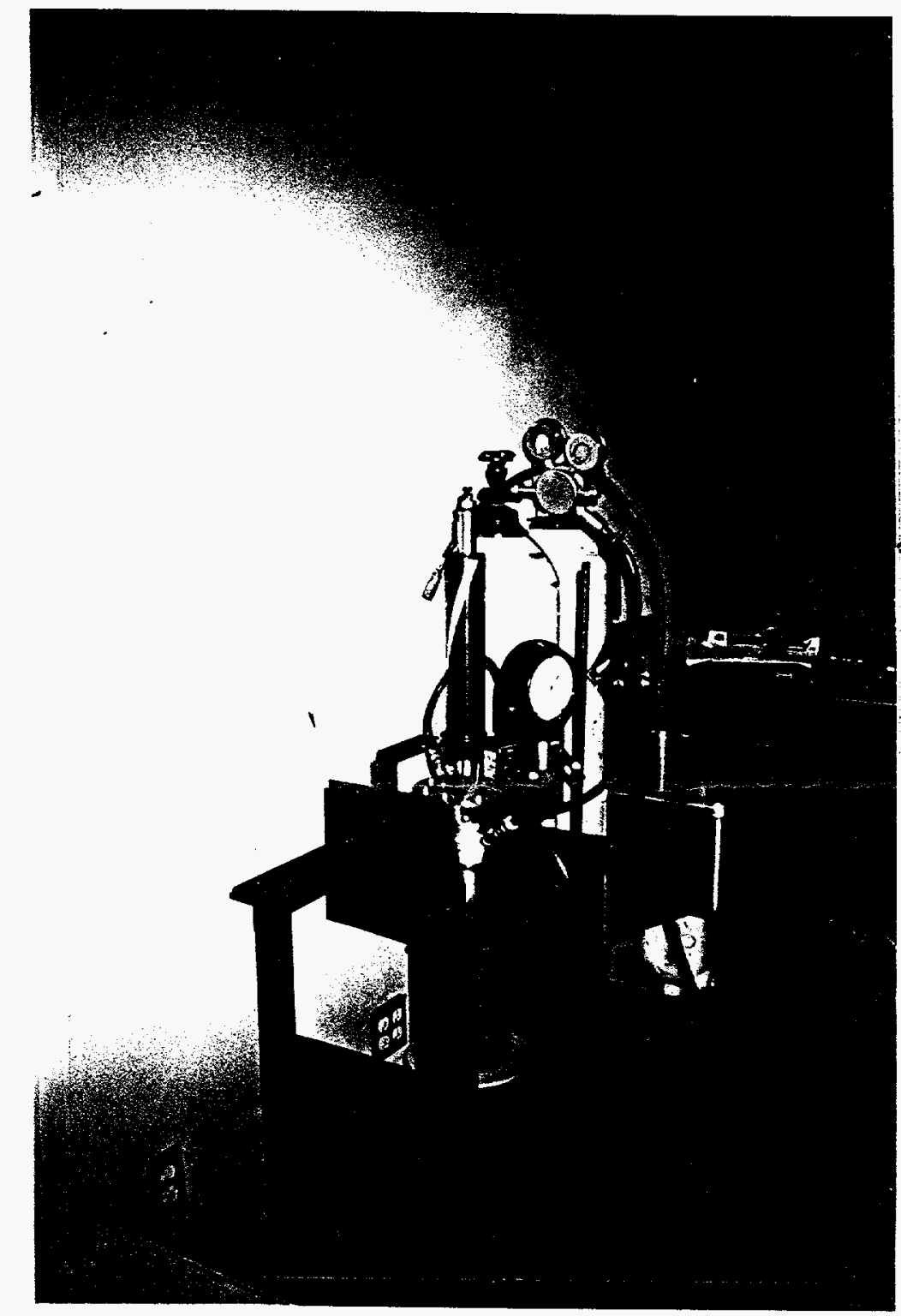

GAS INLET AND OUTLET PORTS FOR SORBENT TESTING 